\section{Cainozoic Plants.}

British Museum (Natural History): Catalogue of Cainozoic Plants in the Department of Geology. Vol. 1 : The Bembridge Flora. By Eleanor Mary Reid and Marjorie Elizabeth Jane Chandler. With a section on the Charophyta, by James Groves. Pp. viii $+206+12$ plates. (London: British Museum (Natural History), 1926.) $15 s$.

THE appearance of the first volume of the catalogue of Cainozoic plants in the British Museum is a noteworthy event. Catalogues of the older plant remains have already appeared, but the great and valuable stores of Tertiary plants in the national collections have received scant attention.

The plant remains of this period are of great interest but present exceptional difficulties ; they are derived chiefly from Angiosperms, often closely resembling modern genera or even species, but usually are represented by leaf impressions only. These are so difficult to identify that many eminent botanists have regarded the task as practically impossible, and have thrown doubt upon the validity of much of the work already done. If, however, we could be sure of the identity of the remains which have come down to us, we should have material of great value for the solution of some of the difficult problems of plant evolution and distribution.

In the present catalogue a number of species are described, identified, and established on grounds which are far more secure than those which Hooker and others have criticised. In the Bembridge beds there are not merely leaf impressions but also the remains, often very well preserved, of seeds and fruits ; many of these can be compared so closely with the seeds and fruits of living plants that it is impossible to doubt the correctness of their determination. The cuticle-structure of some of the leaves is preserved also, and in several cases their identification may be taken as firmly established.

Among the more interesting forms described may be mentioned a new species of Azolla, founded on astonishingly well-preserved material, and most interesting in view of the re-establishment of this genus in England in recent years. Dr. Florin has aided the authors in establishing the presence of a new species of Araucarites, while Sequoia, Cupressus, and Pinus were also present. The majority of the Angiosperms have been compared with plants now existing and have been given suitable generic and specific names, but others which could not be matched with any known living forms are described and placed in the non-committal genera Carpolithus and Dicotylophyllum. The remains of Charophyta are abundant in the flora and have been treated in a separate section by Mr. James Groves, the well-known authority on this group.

One of the most interesting parts of the volume is the introduction, in which, among other matters, the authors give an analysis of the flora and compare it with other fossil and modern floras. It is shown that the Bembridge flora has a greater affinity with the plants living to-day in eastern Asia and North America than with the present European flora, and the authors point out how greatly the recent work on the floras of China and the neighbouring lands affects the determinations and conclusions of the earlier writers on Cainozoic plants.

H. H. T.

\section{Our Bookshelf.}

(1) Wireless Pictures and Television: a Practical Description of the Telegraphy of Pictures, Photographs, and Visual Images. By T. Thorne Baker. Pp. $\mathrm{x}+188$. (London: Constable and Co., Ltd., 1926.) 6s. $6 d$. net.

(2) Television (Seeing by Wire or Wireless). By Alfred Dinsdale. Pp. 62. (London: Sir Isaac Pitman and Sons, Ltd., 1926.) 2s. net.

(1) APPLIED photo-electricity has perhaps developed more rapidly than any other branch of applied physics. The discoveries of outstanding importance which have resulted from photo-electric observations have stimulated the production of improved apparatus, and this has had a healthy reaction upon practical applications. Of these, telephotography and television are among the most interesting. Of the former, Mr. Thorne Baker was one of the most distinguished pioneers, and it is well to have a book on the subject from his pen. The various methods of picture transmission, such as those of Bakewell, Caselli, Charbonelle, Korn, Belin, and others, are described, but considerably more might well have been said about the code method by which Sanger Shepherd transmitted the race for the America Cup. A great deal is naturally said about selenium, and most of it correctly, though the date of discovery of its light-sensitiveness is given as 1861 instead of 1872 , and the very prevalent mistake is made of describing it as particularly sensitive to red light, the great response to which is solely due to the abundance of energy in the red end of the spectra of most terrestrial sources.

The successes achieved by Korn with his selenium transmitter in 1907 have almost been forgotten; the speed was five seconds per line, in spite of the 'lag' of selenium. Portraits were transmitted between Paris, London, and Berlin, of a quality suitable for newspaper reproduction. More recent methods, employing photo-electric cells with a million-fold amplification, may be somewhat speedier but scarcely give a better quality, though giving more detail. The method worked out by Mr.

No. 3007, VoL. 119\} 